\title{
PERAN LINGKUNGAN INDUSTRI, PERILAKU KEWIRAUSAHAAN, DAN KEMAMPUAN MANAJERIAL TERHADAP KINERJA PERUSAHAAN PADA USAHA LOGAM SKALA MIKRO
}

\author{
Shandra Ekaputri \\ Fakultas Ekonomi Universitas Negeri Surabaya \\ Email: e_shandra@yahoo.com \\ Tri Sudarwanto \\ Fakultas Ekonomi Universitas Negeri Surabaya \\ Email: trisudarwanto@unesa.ac.id \\ Novi Marlena \\ Fakultas Ekonomi Universitas Negeri Surabaya \\ Email: novimarlena@unesa.ac.id
}

\begin{abstract}
ABSTRAK
Indonesia adalah salah satu negara berkembang yang memiliki banyak pelaku industri UMKM. Salah satu UMKM tersebut adalah UMKM Logam di Desa Ngingas Sidoarjo yang mampu memasarkan produk sampai pasar internasional. Tujuan penelitian adalah menganalisis peran lingkungan industri, perilaku kewirausahaan, dan kemampuan manajerial yang diterapkan untuk mengukur kinerja perusahaan. Jenis penelitian deskriptif. Teknik pengumpulan data menggunakan observasi terus terang dan taersamar, wawancara tidak terstruktur, dokumentasi, dan triangulasi. Subjek penelitian adalah wirausahawan logam skala mikro, Kepala Desa, dan organisasi logam Ngingas Sidoarjo. Hasil penelitian membuktikan bahwa lingkungan industri pada indikator hambatan masuknya pesaing baru, kekuatan pemasok, kekuatan pembeli, dan ketersediaan barang subsitusi berperan terhadap kinerja perusahaan, sedangkan indikator pesaing kompetitif tidak berperan terhadap kinerja perusahaan. Perilaku kewirausahaan dan kemampuan manajerial berperan terhadap kinerja perusahaan pada usaha logam skala mikro di Ngingas Sidoarjo.
\end{abstract}

Kata kunci: Lingkungan Industri, Perilaku Kewirausahaan, Kemampuan Manajerial, Kinerja Perusahaan. 


\section{PENDAHULUAN}

Pengembangan usaha mikro, kecil dan menengah mulai banyak diperbincangkan, diamati, dan diteliti pada negara maju maupun negara berkembang karena manfaatnya dapat memberikan peranan yang cukup besar bagi keberhasilan ekonomi suatu bangsa. Menurut Shafinaz et al. (2014) bahwa perusahaan kecil dan menengah sebagai "inti ekonom" merupakan suatu alternatif pilihan populer bagi pengusaha karena pada bisnis ini memerlukan lebih sedikit kekayaan, investasi keuangan yang minimal, dan sedikit karyawan. Fakta tersebut membuat banyak perintisperintis pemula yang mengembangkan keahlian mereka dan melihat peluang yang ada untuk membuka usaha kecil sebagai penghasilan mereka.

Kristanto (2009: 37) menyatakan bahwa seharusnya UKM menjadi salah satu prioritas pembangunan bukan hanya dijadikan suatu obyek manuver politik, karena UKM dapat berpotensi menjadi aktor pengerak sektor ekonomi rill dan mengurangan pengangguran. Irawan dan Bayu (2007: 14-15) menyatakan bahwa salah satu kunci keberhasilan untuk membereskan perekonomian disuatu negara adalah dengan menyelesaikan problem dan persoalan yang membelit didalam dunia UMKM. Jumlah UMKM terbanyak sampai tahun 2017 berada di Kabupaten Sidoarjo, hingga kabupaten tersebut dijuluki sebagai Kota UKM Indonesia.

Salah satu UMKM di Sidoarjo yang digunakan sebagai obyek penelitian ini adalah UMKM Logam yang berada di Kampung Logam Desa Ngingas Kecamatan Waru Kabupaten Sidoarjo Propinsi Jawa Timur. Pemasaran produk yang telah sampai ke pasar internasional mengakibatkan banyak dari pengusaha skala menengah yang tidak sangup mengerjakan orderannya sendiri karena jumlah orderan yang cukup banyak, sehingga mereka melimpahkan orderannya ke warga sekitar. Banyaknya warga sekitar yang tertarik untuk ikut membuat orderan, hingga akhirnya mereka juga banyak yang tertarik untuk mendirikan usaha sendiri. Dari fenomena tersebut membuat banyak bermunculan pelaku-pelaku usaha baru yang ingin bersaing dengan usaha yang lebih dahulu berkembang. Banyaknya UMKM yang ada membuat persaingan usaha semakin ketat dan hal ini berpengaruh terhadap kinerja dari setiap UMKM. Banyak para pelaku usaha yang hanya ingin coba-coba dalam mendirikan dan mengelola usaha, namun terpaksa mereka banyak yang gulung tikar. 
Untuk tetap bertahan dalam menghadapi persaingan sejenis dan lingkungan industri yang selalu berubah, suatu perusahaan baik skala usaha mikro hingga menengah harus memaksimalkan kinerja perusahaan sehingga tujuan yang direncanakan dapat tercapai. Kinerja perusahaan pada usaha skala mikro di UMKM Logam Ngingas Sidoarjo sempat mengalami penurunan penjualan yang terjadi pada tahun 2008. Penurunan tersebut dikarenakan pengusaha skala menengah yang kurang memberi order produk logam ke pengusaha skala mikro, banyaknya produk logam dari China yang telah memasuki pangsa pasar di Indonesia semakin memberatkan pelaku usaha logam. Agar produknya tetap diminati dipasar dan tidak kalah dengan produk dari China, banyak dari pelaku usaha yang menurunkan harga jual jual sehingga produk tetap bisa bersaing dipasar. Banyaknya pelaku usaha logam yang guling tikir disinyalir peneliti disebabkan karena faktor lingkungan industri, perilaku kewirausahaan, dan kemampuan manajerial yang kurang baik dibandingkan pesaing sejenisnya yang lebih mampu untuk konsisten dalam mengelola usahanya

Faktor lingkungan industri menurut Solihin (2009: 39) merupakan lingkungan yang memiliki pengaruh langsung terhadap keberhasilan suatu perusahaan karena perusahaan memiliki interaksi langsung dengan faktor - faktor yang ada disekitarnya. Adanya produk logam dari Cina yang membuat persaingan semakin ketat, banyaknya produk subititusi pengganti logam misalnya plastik juga sebagai penghambat permintaan produk logam. Udaya (2013: 57) menjelaskan indikator lingkungan industri dinilai dari hambatan masuknya pesaing baru, kekuatan pemasok, kekuatan pembeli, ketersediaan barang subsitusi, dan pesaing kompetitif.

Faktor kedua yaitu perilaku kewirausahaan yang merupakan perilaku wirausahawan dalam mengelola usahanya. UMKM Logam Ngingas hampir semua melakukan proses produksi karena adanya order yang didapat baik dari usaha skala menengah, pelanggan, sales perusahaan, dan konsumen perorangan. Beberapa pelaku usaha ada yang tetap melakukan proses produksi meskipun sedang tidak ada pesanan walaupun hanya dalam jumlah yang sedikit.

Pada faktor ketiga yang juga sebagai peranan adanya kinerja perusahaan adalah faktor kemampuan manajerial yang merupakan kemampuan dari seorang wirausaha dalam mengelola usahanya, dimana perusahaan tersebut akan berhasil apabila manajemennya baik dan teratur dalam menjalankan fungsi manajemen. Kemampuan 
manajerial yang dilakukan pada UMKM Logam skala usaha mikro hanya terbatas pada pemikirkan perencanaan bisnis seperti memperluas jangkauan pasar dengan cara memperkenalkan produk hasil buatannya ke perusahaan yang membutuhkan dengan mengunakan pemasaran door to door dengan membawa sampel produk ke calon konsumennya, selalu berkomunikasi dan mengorganisasi karyawan terkait dengan produk yang akan diproduksi, dan yang terakhir melakukan pengawasan terkait dengan jalannya proses produksi hingga barang dikirim kepada pelanggan atau konsumen sehingga produk sesuai permintaan dan selesai tepat waktu.

\section{Rumusan Masalah}

1. Bagaimana peran lingkungan industri terhadap kinerja perusahaan pada Usaha Logam skala mikro di Ngingas Sidoarjo?

2. Bagaimana peran perilaku kewirausahaan terhadap kinerja perusahaan pada Usaha Logam skala mikro di Ngingas Sidoarjo?

3. Bagaimana peran kemampuan manajerial terhadap kinerja perusahaan pada Usaha Logam skala mikro di Ngingas Sidoarjo?

\section{Tujuan Penelitian}

1. Untuk mengetahui bagaimana peran lingkungan industri terhadap kinerja perusahaan pada Usaha Logam skala mikro di Ngingas Sidoarjo.

2. Untuk mengetahui bagaimana peran perilaku kewirausahaan terhadap kinerja perusahaan pada Usaha Logam skala mikro di Ngingas Sidoarjo.

3. Untuk mengetahui bagaimana peran kemampuan manajerial terhadap kinerja perusahaan pada Usaha Logam skala mikro di Ngingas Sidoarjo.

\section{TELAAH PUSTAKA}

\section{Peran Lingkungan Industri}

Lingkungan industri menurut Solihin (2009: 39) merupakan lingkungan yang memiliki pengaruh langsung terhadap keberhasilan suatu perusahaan karena perusahaan memiliki interaksi langsung dengan faktor - faktor yang ada disekitarnya, faktor - faktor tersebut antara lain masuknya pesaing baru, pemasok, pembeli, ketersediaan produk substitusi, dan pesaing kompetitif. Porter membuat kerangka kerja konseptual model 
lima kekuatan (five forces model) yang nantinya dapat membantu manajer dalam menganalisis lingkungan industri.

Jones dan Hill (2009) dalam Udaya (2013: 64-73) menjelaskan model lima kekuatan untuk menilai lingkungan industri, diantaranya:

1. Resiko masuknya pesaing potensial, pesaing potensial tidak lain adalah perusahaanperusahaan yang pada saat ini tidak bersaing dalam dunia industri, tetapi ia memiliki kemampuan untuk melakukannya bila mereka menginginkannya. Masuknya pesaing baru akan berpotensi mengurangi keuntungan dari perusahaan-perusahaan yang sudah ada, karena mereka tidak mungkin meminta harga tinggi bagi produk-produk yang akan ditawarkannya.

2. Kekuatan tawar-menawar para pemasok, pemasok memiliki posisi tawar-menawar yang berbeda-beda terhadap perusahaan. Kemampuan pemasok untuk menentukan syarat-syarat perdagangan yang menguntungkan bagi dirinya dan kurang menguntungkan bagi perusahaan atau membuat syarat-syarat perdagangan yang menguntungkan kedua belah pihak kan berpengaruh terhadap kinerja dari perusahaan tersebut. Apabila perusahaan dapat memperoleh pasokan bahan baku dari beberapa pemasok maka kedudukan perusahaan relatif lebih kuat dibandingkan pemasok, sehingga pemasok tidak memberikan ancaman yang berarti bagi perusahaan.

3. Kekuatan tawar-menawar para pembeli, yang dimaksud dengan para pembeli industri adalah para pelanggan individual (pembeli akhir) dan perusahaanperusahaan yang mengelola kembali produk tersebut (B2B). Kekuatan tawarmenawar dari pembeli adalah kemampuan para pembeli untuk menawar harga dari perusahaan dalam industri ke tingkat yang lebih rendah, atau untuk meningkatkan biaya perusahaan dengan menimta kualitas serta layanan yang baik terhadap produkproduknya.

4. Ancaman dari produk-produk substitusi, persaingan terhadap produk yang dihasilkan perusahaan tidak hanya berasal dari perusahaan yang memproduksi produk yang sama sehingga memberikan akibat persaingan langsung, melainkan juga dapat dilihat dari perusahaan yang menghasilkan produk dengan memiliki kesamaan fungsi dengan produk yang dihasilkan perusahaan. 
5. Persaingan diantara perusahaan-perusahaan yang ada, didalam industri selalu terjadi persaingan antar perusahaan dengan perusahaan yang lainnya. Intensitas persaingan antar perusahaan dalam industri sangat dipengaruhi oleh faktor pertumbuhan industri, ketidakmampuan memproduksi pesanan, produk yang dihasilkan sama, dan harga yang dihasilkan cukup tinggi.

\section{Perilaku Kewirausahaan}

Perilaku kewirausahaan merupakan karakter seorang wirausaha dalam menjalankan roda bisnisnya (Hamdani, 2010:43). Sedangkan menurut Mc Clelland (2000) dalam Suryana (2013:52) perilaku kewirausahaan merupakan konsep tingkah laku wirausahawan sebagai pengambil resiko yang moderat. Berdasarkan kedua pengertian tersebut perilaku kewirausaan merupakan sikap, tingkah laku wirausahawan dalam mengelola usahanya. Sikap dan tingkah laku tersebut nantinya diharapkan mampu memberikan pertumbuhan dan perkembangan bagi usaha yang sedang dikelolanya.

Scarborough (1993) dalam Zakiyudin (2013: 30) menjabarkan tiga indikator yang digunakan untuk mengukur ketepatan perilaku wirausaha dalam menjalankan usahanya yang terdiri dari:

1. Proaktif, sikap seseorang yang mampu mengenali kesempatan dan memanfaatkannya sehingga menghasilkan perubahan kearah yang lebih baik. Orang dengan sikap proaktif tidak sekedar bereaksi terhadap berbagai keadaan tetapi memiliki inisiatif untuk melakukan aksi terhadap perubahan. Wirausaha yang proaktif memiliki ciriciri sebagai berikut:

a. Selalu memiliki inisiatif untuk melakukan hal-hal yang bermanfaat bagi perusahaan.

b. Tegas dalam melaksanakan tugas tanpa menyalahkan orang lain dengan membuat keputusan secara bijak tanpa terpengaruh hati maupun keadaan.

2. Berorientasi pada prestasi, pengusaha yang baik selalu mengejar prestasi yang lebih baik dari pada prestasi sebelumnya, dimana dalam berorientasi pada prestasi atau kemajuan memiliki ciri-ciri sebagai berikut:

a. Selalu mencari peluang baru.

b. Konsen pada kerja keras. 
3. Komitmen pada pihak lain, komitmen dengan pihak lain merupakan ciri yang harus dipegang teguh dan harus ditepati. Komitmen pada pihak lain diantaranya pada perusahaan atau orang lain, memiliki ciri-ciri:

a. Selalu memegang teguh kontrak kerja.

b. Mengenal tentang betapa pentingnya hubungan bisnis.

\section{Kemampuan Manajerial}

Kemampuan manajerial merupakan kesangupan mengambil tindakan-tindakan perencanaan, pengorganisasian, pelaksanaan, dan pengawasan yang dilakukan untuk mencapai sasaran yang telah ditentukan (Setyamusa, 2009: 28). Sedangkan menurut Sutarno (2012: 26) kemampuan manajerial adalah kemampuan dari seorang manajer atau wirausaha dalam mengelola usahanya, dimana perusahaan tersebut akan berhasil apabila manajemennya baik dan teratur dalam menjalankan fungsi manajemen. Dari kedua definisi tersebut disimpulkan bahwa kemampuan manajerial merupakan kemampuan yang dimiliki oleh seorang pengelola usaha, dimana kemampuan tersebut diantaranya adalah mampu untuk membuat suatu perencanaan bisnis, pengorganisasian karyawan, pelaksanaan, dan pengawasan dalam usaha yang dilakukan

\section{Kinerja Perusahaan}

Kinerja perusahaan merupakan suatu cara untuk mendapatkan hasil yang lebih baik bagi organisasi, kelompok, dan individu dengan cara memahami dan mengelola kinerja sesuai dengan target yang telah direncanakan, stbapak/iburt, dan persyaratan kompetensi yang telah ditentukan (Dharma, 2009: 26). Sedangkan menurut P. Stephen dan Coulter (2010: 219) manajemen kinerja perusahaan merupakan hasil dari sebuah aktivitas kerja dalam perusahaan, dimana untuk mendapatkan hasil yang maksimal sesuai tujuan perusahaan maka manajer perusahaan perlu memahami dan mengelola kinerja sesuai dengan target yang telah ditentukan sebelumnya.Berdasarkan kedua definisi tersebut dapat dapat disimpulkan bahwa manajemen kinerja perusahaan merupakan sebuah proses perusahaan atau organisasi dengan tujuan untuk menetapkan apa yang harus dicapai, dan pendekatan untuk mengelola dan mengembangkan sumberdaya yang dimiliki perusahaan sehingga mendapatkan hasil akhir sesuai dengan target yang diinginkan. Menurut Rahayu (2013: 65-66) indikator dalam mengukur kinerja perusahaan sebagai berikut: 
1. Peningkatan penjualan, peningkatan penjualan diukur menurut penilaian subyek responden dengan rata-rata tingkat kenaikan penjualan selama tiga tahun terakhir.

2. Peningkatan profit, peningkatan keuntungan atau laba perusahaan pengukurannya sama dengan peningkatan penjualan. Pengukurannya dinilai dari rata-rata tingkat keuntungan perusahaan selama kurun waktu tiga tahun terakhir.

3. Pertumbuhan memuaskan, dengan menilai seberapa puas wirausahawan terhadap tingkat pertumbuhan usaha selama kurun waktu tiga tahun terakhir.

\section{Kerangka Pemikiran}

\section{Fenomena}

Dikarenakan hanya ingin coba-coba dalam mendirikan usaha mengakibatkan beberapa usaha skala mikro terpaksa gulung tikar dan terjadinya perbedaan penjualan yang cukup tinggi bila dibandingkan dengan penjualan pada usaha skala kecil dan menengah menyebabkan penulis tertarik untuk melakukan penelitian pada Usaha Logam skala mikro yang masih berdiri hingga sekarang terkait dengan kinerja perusahaan setiap tahunnya dengan melihat lingkungan industri yang dinamis, perilaku kewirausahaan, dan kemampuan manajerial yang dilakukan.

\begin{tabular}{|c|c|}
\hline Harapan & Kenyataan \\
\hline $\begin{array}{l}\text { 1. Faktor lingkungan industri } \\
\text { menentukan kinerja perusahaan UMKM } \\
\text { Logam. }\end{array}$ & $\begin{array}{lrr}\text { 1. Persaingan dengan UMKM } & \text { sejenis } \\
\text { maupun produk dari } & \text { luar } \\
\text { mempengaruhi kinerja UMKM. } & \end{array}$ \\
\hline $\begin{array}{l}\text { 2. Faktor perilaku kewirausahaan } \\
\text { menentukan kinerja perusahaan UMKM } \\
\text { Logam. }\end{array}$ & $\begin{array}{l}\text { 2. Perilaku wirausaha terhadap } \\
\text { pelanggan hanya dengan menepati } \\
\text { kesepakatan dan menjaga komunikasi. }\end{array}$ \\
\hline 2 Faktor kemamnuan manaierial & 2 Funoci POAC dilakukan denoan \\
\hline
\end{tabular}

\begin{tabular}{|c|c|c|}
\hline \multicolumn{3}{|c|}{ Faktor-faktor yang mempengaruhi aktivitas wirausaha } \\
\hline $\boldsymbol{V}$ & $\downarrow$ & $\nabla$ \\
\hline$\underset{\substack{\text { Lin } \\
\text { Lingkungan Industri }}}{\cos }$ & $\begin{array}{c}\text { Perilaku Kewirausahaan } \\
\text { (X2) }\end{array}$ & $\begin{array}{c}\text { Kemampuan } \\
\text { Monoinmiol (Y) }\end{array}$ \\
\hline $\begin{array}{l}\text { 1. Hambatan masuknya } \\
\text { pesaing baru } \\
\text { 2. } \text { Kekuatan pemasok } \\
\text { 3. } \text { Kekuatan pembeli } \\
\text { 4. } \text { Ketersediaan barang } \\
\text { Subsitusi } \\
\text { 5 } \text { Dacninn 1rnmnotitif }\end{array}$ & $\begin{array}{l}\text { 1. Proaktif } \\
\text { 2. Berorientasi pada } \\
\text { prestasi } \\
\text { 3. Komitmen pada pihak } \\
\text { lain }\end{array}$ & $\begin{array}{l}\text { 1. Perencanaan } \\
\text { 2. Pengorganisasian } \\
\text { 3. Pelaksanaan } \\
\text { 4. Pengawasan }\end{array}$ \\
\hline
\end{tabular}

Kinerja Perusahaan pada Usaha Logam Skala Mikro di Ngingas Sidoario (Y)

Sumber : Data diolah peneliti, 2018

Gambar 1. Kerangka pemikiran peran lingkungan industri, perilaku kewirausahaan, kemampuan manajerial terhadap kinerja perusahan pada usaha logam Ngingas 


\section{METODE PENELITIAN}

Jenis penelitian ini adalah jenis penelitian deskriptif. Teknik pengumpulan data berupa observasi terus terang dan tersamar, wawancara tidak terstruktur, dokumentasi, dan triangulasi data. Subjek dan objek penelitian dibagi menjadi dua yaitu informan kunci adalah pemilik atau pengelola usaha logam skala mikro di Ngingas Sidoarjo dan informan pendukung terdiri dari Kepala Desa Ngingas dan organisasi logam yang menaunggi UMKM Logam Ngingas. Penentuan subjek atau informan pada penelitian ini adalah dengan mengunakan purposive sampling. Teknik analisis data dilakukan melalui empat tahap yaitu:

1. Pengumpulan Data (data collection)

Peneliti mengunakan teknik pengumpulan data berupa observasi, wawancara, dokumentasi, dan triangulasi. Dimana nantinya seluruh data yang terkumpul akan dibaca, dipelajari, dan ditelaah. Analisis data dapat dilakukan sejak pengumpulan data sewaktu peneliti berada dilapangan hingga data dianyatakan layak dan sudah benar.

2. Reduksi Data (data reduction)

Data yang diperoleh dari lapangan jumlahnya cukup banyak, untuk itu maka perlu dicatat secara rinci dan teliti. Semakin lama peneliti berada dilapangan, maka data yang ada akan semakin banyak, kompleks, dan rumit. Untuk itu perlu dilakukan analisis data melalui reduksi data. Ddata yang diambil dari proses reduksi data hanyalah yang berkaitan dengan lingkungan industri yang sedang terjadi pada usaha logam skala mikro di Ngingas Sidoarjo, perilaku kewirausahaan dan kemampuan manajerial yang dilakukan dalam mengelola usaha sehingga mampu untuk menilai kinerja dari setiap usaha logam skala mikro di Ngingas Sidoarjo.

3. Penyajian Data (data display)

Penyajian data dilakukan melalui uraian singkat yang berbentuk naratif, bagan, hubungan antar kategori, flowchart, dan sejenisnya. Dengan teknik penyajian data maka akan memudahkan untuk memahami apa yang terjadi dan merencanakan kerja selanjutnya berdasarkan yang telah difahami tersebut.

4. Penarikan Kesimpulan atau Verifikasi (conclusions drawing)

Pada tahap ini peneliti berusaha mencari makna dari data yang dikaji, data yang dikaji merupakan data yang diperoleh melalui kegiatan observasi, wawancara, 
dokumentasi, dan triangulasi data mengenai kondisi kinerja prusahaan pada usaha logam skala mikro yang dilihat melalui perkembangannya selama kurun waktu tiga tahun dimana pengaruhnya dilihat dari lingkungan industri yang terjadi, perilaku kewirausahaan, dan kemampuan manajerial yang diterapkan dalam masing-masing usaha logam skala mikro di Ngingas Sidoarjo.

\section{HASIL DAN PEMBAHASAN}

Fokus penelitian membahas tentang kinerja perusahaan logam skala mikro di Ngingas Sidoarjo, maka informan kunci yang dijadikan sebagai subjek penelitian adalah pemilik atau pelaku usaha logam skala mikro yang berjumlah sembilan orang. Informan kunci tersebut dimintai pendapat tentang perkembangan kinerja perusahaan selama tiga tahun terakhir, peran lingkungan industri, perilaku kewirausahaan, dan kemampuan manajerial. Berdasarkan jawaban dari informan kunci dari masing-masing variabel dijelaskan sebagai berikut:

\section{Peran Lingkungan Industri terhadap Kinerja Perusahaan pada Usaha Logam Skala} Mikro di Ngingas Sidoarjo

Lingkungan industri merupakan lingkungan yang memiliki pengaruh langsung terhadap keberhasilan suatu perusahaan karena perusahaan memiliki interaksi langsung dengan faktor-faktor yang ada disekitarnya, faktor - faktor tersebut antara lain masuknya pesaing baru, pemasok, pembeli, ketersediaan produk substitusi, dan pesaing kompetitif. 
Tabel 1. Hasil jawaban Informan Kunci terkait peran lingkungan industri

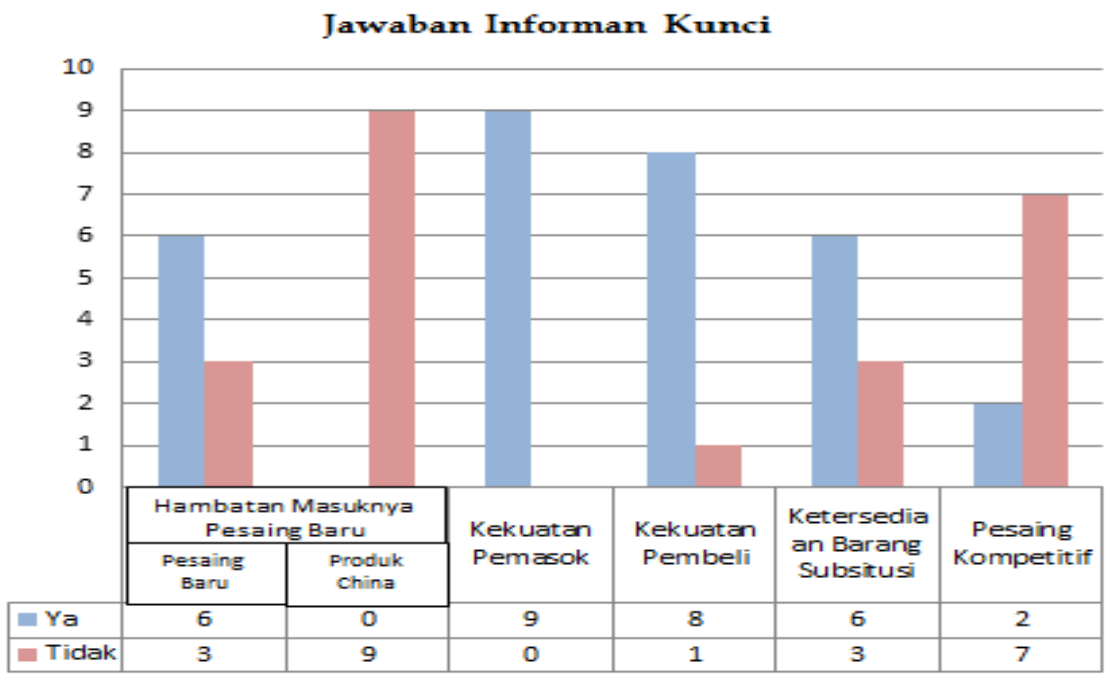

Berdasarkan tabel 1 tersebut dapat dijelaskan sebagai berikut:

1. Hambatan Masuknya Pesaing Baru "Pesaing Baru"

Indikator pertama yaitu hambatan masuknya pesaing baru "pesaing baru" item pernyataan nomor 1 dapat diketahui bahwa tiga informan kunci menjawab "Tidak" yang artinya munculnya pesaing baru tidak menguranggi penjualan usaha namun sebanyak enam informan kunci menjawab "Ya" yang artinya tetap berpendapat bahwa munculnya pesaing baru mampu menguranggi penjualan setiap tahunnya.

2. Hambatan Masuknya Pesaing Baru "Produk China"

Indikator pertama hambatan masuknya pesaing baru "produk China" juga diukur mengunakan item pernyataan nomor 2 memberikan hasil bahwa secara keseluruhan atau sebesar sembilan informan kunci menjawab "Tidak" yang artinya bahwasannya produk dari China tidak menguranggi penjualan usaha mereka.

3. Kekuatan Pemasok

Indikator kedua yaitu kekuatan pemasok pada item pernyataan nomor 3 keseluruhan informan kunci atau sebesar sembilan informan kunci menjawab "Ya" yang artinya bahwa memiliki banyak pemasok bahan baku mampu memberikan keuntungan pada usaha mereka.

4. Kekuatan Pembeli

Indikator ketiga kekuatan pembeli atau kekuatan tawar-menawar para pembeli hasil penelitiannya dapat dilihat pada item pernyataan nomor 4, dimana dalam hasil item pernyataan tersebut dapat dilihat bahwa delapan informan kunci menjawab "Ya" 
yang artinya tawar-menawar terhadap harga produk tetap akan berpengaruh pada pembelian konsumen dan satu informan kunci menjawab "Tidak" yang artinya tawar-menawar terhadap harga produk tidak berpengaruh pada pembelian konsumen.

\section{Ketersediaan Barang Subsitusi}

Indikator keempat ketersediaan barang subsitusi pada item pernyataan nomor 5 memberikan hasil penelitian sebanyak enam informan kunci menjawab "Ya" yang artinya bahwa produk subsitusi mampu menguranggi penjualan usaha mereka dan tiga informan kunci menjawab "Tidak" yang artinya produk subsitusi tidaklah menguranggi penjualan usaha mereka.

6. Pesaing Kompetitif

Indikator kelima yaitu pesaing kompetitif banyaknya usaha-usaha logam disekitar usaha mereka tidak membuat informan kunci berpendapat bahwa banyaknya pesaing disekitar usaha mereka menguranggi penjualan disetiap tahunnya. Terbukti dengan hasil pendapat dari informan kunci yang dapat dilihat pada item pernyataan nomor 6 bahwa sebanyak tujuh informan kunci menjawab "Tidak" yang artinya banyaknya usaha logam disekitar usaha mereka tidak menguranggi penjualan setiap tahunnya dan dua informan kunci menjawab "Ya" yang artinya banyaknya usaha logam di sekitar usaha mereka mampu menguranggi penjualan setiap tahunnya.

Hasil penelitian menunjukkan bahwa lingkungan industri yang terdiri dari indikator hambatan masuknya pesaing baru, kekuatan pemasok, kekuatan pembeli, dan ketersediaan barang subsitusi berperan terhadap kinerja perusahaan, namun untuk indikator pesaing kompetitif dinilai tidak berperan terhadap kinerja perusahaan pada usaha logam skala mikro di Ngingas Sidoarjo. Indikator pertama pernyataan pertama yaitu hambatan masuknya pesaing baru "pesaing baru" bahwa munculnya pesaing baru mampu menguranggi penjualan usaha mereka, karena pesaing baru yang lebih kompetitif dan memahami pasar akan dianggap mampu menarik pelanggan tetap mereka. Langkah yang harus dilakukan menurut informan kunci agar penjualan tetap konsisten adalah dengan melakukan promosi langsung, menyediakan produk yang diinginkan pasar, menjaga kualitas produk dan komunikasi dengan konsumen. Indikator pertama pernyataan kedua yaitu hambatan masuknya pesaing baru "produk China" ternyata tidak berperan dalam kinerja perusahaan, karena pemilik ataupun pengelola 
usaha logam yang ada di Ngingas Sidoarjo sebanyak sembilan informan berpendapat bahwa competitor utamanya bukan dari produk China sehingga pesaing baru yaitu produk dari China tidak menguranggi penjualan usaha mereka. Indikator kedua pernyataan ketiga yaitu kekuatan pemasok. Memiliki banyak pemasok akan mempu memberikan keuntungan pada usaha mereka. Setiap usaha logam skala mikro yang ada disana memiliki minimal 3 pemasok hingga lebih dari 10 pemasok. Banyaknya pemasok yang dimiliki tersebutlah pemilik atau pelaku usaha mampu memilah pemasok yang mampu memberikan keuntungan pada usaha mereka.Indikator ketiga pada pernyataan keempat kekuatan pembeli. Dari hasil penelitian diketahui bahwa harga produk yang ditawarkan oleh pemilik atau pengelola usaha akan berpengaruh pada pembelian konsumen. Kisaran harga yang digunakan untuk menentukan harga jual produk logam tiap-tiap usaha berfariasi, harga jual yang diterapkan disana berdasarkan ukuran per-kg dan per-unit produk sesuai dengan jenis produk yang dihasilkan.Indikator keempat item pernyataan kelima ketersediaan barang subsitusi bahwa produk yang memiliki kesamaan fungsi mampu menguranggi penjualan usaha mereka. Jenis-jenis produk subsitusi menurut pendapat informan kunci yang mampu mempengaruhi penjualan adalah berupa produk dari bahan baku logam bekas, produk memiliki fungsi yang sama namun bentuknya berbeda, produk yang terbuat dari non logam seperti plastik, dan produkproduk inovasi yang memiliki kecanggihan lebih dari pada produk yang dihasilkan. Indikator kelima pada pernyataan keenam pesaing kompetitif tidak menjadi suatu hal yang rawan dalam mengelola usaha logam skala mikro di Ngingas Sidoarjo meskipun banyak sekali usaha-usaha yang berdiri disekitar usaha mereka karena usaha logam Ngingas memiliki banyak cluster produk logam sehingga produk yang dihasilkan berbeda dan walaupun terdapat produk yang sama namun banyak dari mereka yang telah memiliki pelanggan tetap. Hal tersebut diperkuat oleh penelitian Hajar dkk (2012) tentang lingkungan industri berpengaruh positif dan signifikan terhadap kemampuan organisasi dan kinerja perusahaan, namun Puji (2009) dalam penelitiannya memberikan pendapat yang berbeda bahwa dinamika lingkungan yaitu tentang itensitas persaingan tidak memberikan pengaruh terhadap kinerja industri bordir di Jawa Timur.

Peran Perilaku Kewirausahaan terhadap Kinerja Perusahaan pada Usaha Logam Skala Mikro di Ngingas Sidoarjo 
Perilaku kewirausahaan merupakan konsep tingkah laku wirausahawan sebagai pengambil resiko yang moderat. Scarborough (1993) dalam Zakiyudin (2013: 30) menjabarkan tiga indikator yang digunakan untuk mengukur ketepatan perilaku wirausaha dalam menjalankan usahanya, dimana ketiga indikator tersebut antara lain proaktif, berorientasi pada prestasi, dan komitmen pada pihak lain.

Tabel 2 Hasil jawaban Informan Kunci terkait perilaku kewirausahaan

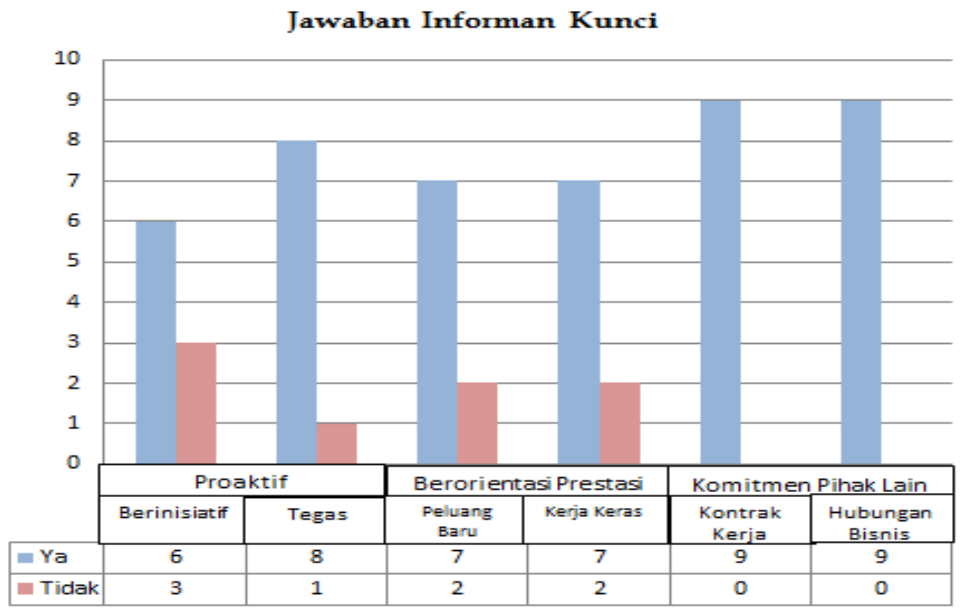

Berdasarkan tabel 2 tersebut dapat dijelaskan sebagai berikut:

1. Proaktif "Berinisiatif Menghubunggi Pelanggan"

Indikator pertama proaktif yang dicirikan dengan sikap pertama yaitu "berinisiatif menghubunggi pelanggan" pada item pernyataan nomor 1 yang berbunyi pemilik atau pengelola usaha selalu berinisiatif menghubunggi pelanggan apabila produk yang dikerjakan telah sedikit dijawab "Ya" oleh enam informan kunci dan tiga informan kunci menjawab "Tidak".

2. Proaktif "Tegas dalam Menjalankan Tugas"

Indikator pertama proaktif yang dicirikan dengan sikap kedua yaitu "tegas dalam menjalankan tugas" memberikan hasil bahwasannya penilaian sikap tegas yang dilakukan oleh pemilik atau pengelola usaha logam di Ngingas tercermin pada item pernyataan nomor 2 , dimana pada pernyataan tersebut sebanyak delapan informan kunci menjawab "Ya" yang artinya mereka selalu bersikap tegas dalam membuat keputusan dan satu informan kunci menjawab "Tidak" yang artinya tidak bersikap tegas dalam membuat keputusan yang berhubungan dengan mengelola usaha. 


\section{Berorientasi pada Prestasi "Selalu Mencari Peluang Baru"}

Indikator kedua brorientasi pada prestasi yang dicirikan dengan sikap wirausahawan yang selalu mencari peluang baru demi pertumbuhan usahannya memberikan hasil seperti pada item pernyataan nomor 3, yaitu sebanyak tujuh informan kunci menjawab "Ya" yang artinya selalu mencari peluang baru demi pertumbuhan usaha dan sebanyak dua informan kunci menjawab "Tidak" yang artinya mereka tidak mencari peluang baru demi pertumbuhan usaha.

4. Berorientasi pada Prestasi "Konsen pada Kerja Keras"

Indikator kedua berorientasi pada juga dicirikan dengan sikap wirausahawan yang harus mampu konsen pada kerja keras yang tinggi dalam mengelola usahanya demi pertumbuhan usaha setiap tahunnya. Hasil penelitian pada indikator berorientasi pada prestasi yang dicirikan dengan sikap konsen pada kerja keras item pernyataan nomor 4 memberikan hasil sebanyak tujuh informan kunci menjawab "Ya" yang artinya selalu berkonsentrasi pada kerja keras yang tinggi dalam mengelola usaha logam dan sebanyak dua informan kunci menjawab "Tidak" melakukannya.

5. Komitmen pada Pihak Lain "Memegang Teguh Kontrak Kerja" Indikator ketiga yaitu komitmen pada pihak lain yang dicirikan dengan sikap memegang teguh kontrak kerja item pernyataan nomor 5 yang membahas tentang kontrak kerja selalu menjadi prioritas utama agar pihak yang terkait tidak merasa kecewa dijawab dengan keseluruhan informan kunci menjawab "Ya" yang artinya selalu memprioritaskan kontrak kerja dalam mengelola usahanya.

6. Komitmen pada Pihak Lain "Pentingnya Hubungan Bisnis" Indikator ketiga komitmen pada pihak lain yang dicirikan dengan memiliki sikap untuk menjaga hubungan bisnis tertera pada hasil penelitian item pernyataan 6 yang membahas tentang betapa pentingnya hubungan bisnis dijawab oleh keseluruhan informan kunci "Ya" yang artinya menjaga hubungan bisnis sangat penting dalam menjalankan usaha logam.

Berdasarkan penelitian yang dilakukan maka mendapatkan hasil bahwa perilaku kewirausahaan berperan terhadap kinerja perusahaan pada usaha logam skala mikro di Ngingas Sidoarjo. Indikator pertama proaktif dengan menilai sikap wirausahawan yang berinisiatif menghubunggi pelanggan pada item pernyataan pertama memberikan hasil bahwa mereka selalu berinisiatif menghubunggi pelanggan tetapnya apabila produk yang 
dikerjakan telah sedikit dengan tujuan untuk mengangkat usaha dan penghasilan yang didapatkan tetap konsisten. Indikator pertama proaktif dengan sikap tegas dalam menjalankan tugas pada item pernyataan kedua memberikan hasil bahwa mereka selalu bersikap tegas dalam membuat keputusan yang berhubungan dengan mengelola usaha. Hal-hal yang mengharuskan pemilik bersikap tegas adalah yang berkaitan tentang menjaga kedisiplinan karyawan, penetapan harga jual produk, scadule penjualan, menepati janji dengan konsumen, dan menjaga motto perusahaan.Indikator kedua berorientasi pada prestasi dengan sikap selalu mencari peluang baru pada pernyataan ketiga memberikan hasil bahwa mereka selalu mencari peluang baru demi pertumbuhan usaha. Beberapa peluang yang dilakukan pemilik atau pengelola usaha seperti pada mencari bahan baku semurah-murahnya, mengunakan media online dalam memasarkan produk, inovasi produk, dan membuat produk baru. Indikator kedua berorientasi pada prestasi dengan ciri-ciri sikap konsen pada kerja keras pada item pernyataan keempat memberikan hasil bahwa mereka selalu berkonsentrasi pada kerja keras yang tinggi dalam mengelola usaha logam. Tujuan dilakukannya konsen pada kerja keras akan memberikan pendapatan dan sarana-prasarana yang meningkat bagi suatu usaha. Indikator ketiga komitmen pada pihak lain dengan bercirikan sikap memegang teguh kontrak kerja pada item pernyataan nomor lima memberikan hasil bahwa kontrak kerja selalu menjadi prioritas utama agar pihak yang terkait tidak merasa kecewa. Pada usaha logam skala mikro di Ngingas Sidoarjo jenis kontrak kerja yang dimaksut adalah kontrak kerja yang berupa perjanjian secara lisan tanpa adanya perjanjian tertulis.Indikator ketiga komitmen pada pihak lain dengan sikap menjaga pentingnya hubungan bisnis pada item pernyataan keenam memberikan hasil bahwa menjaga hubungan bisnis sangat penting dalam menjalankan usaha logam. Tujuan dan keutamaan dari menjaga hubungan bisnis adalah agar menciptakan loyalitas pada pelanggan tetap sehingga pendapatan tiap tahunnya semakin meningkat. Hasil penelitian ini sejalan dengan penelitian Kraus (2012) tentang pentingnya orientasi kewirausahaan yang positif berkontribusi terhadap kinerja UKM selama krisis ekonomi yang berlangsung di Belanda dan penelitian Nur (2014) orientasi kewirausahaan memainkan peran penting untuk meningkatkan orientasi pasar, strategi bisnis, dan kinerja perusahaan pada UKM Printing di Kendari. 


\section{Peran Kemampuan Manajerial terhadap Kinerja Perusahaan pada Usaha Logam Skala Mikro di Ngingas Sidoarjo}

Kemampuan manajerial adalah kemampuan dari seorang manajer atau wirausaha dalam mengelola usahanya, dimana perusahaan tersebut akan berhasil apabila manajemennya baik dan teratur dalam menjalankan fungsi manajemen. Dalam penelitian kemampuan manajerial yang baik R, George (2010) dalam Sutarno (2012: 26) menyebutkan indikator-indikator yang mampu digunakan untuk mengukur kemampuan manajerial diantaranya perencanaan, pengorganisasian, pelaksanaan, dan pengawasan

Tabel 3 Hasil jawaban Informan Kunci terkait peran kemmapuan manajerial

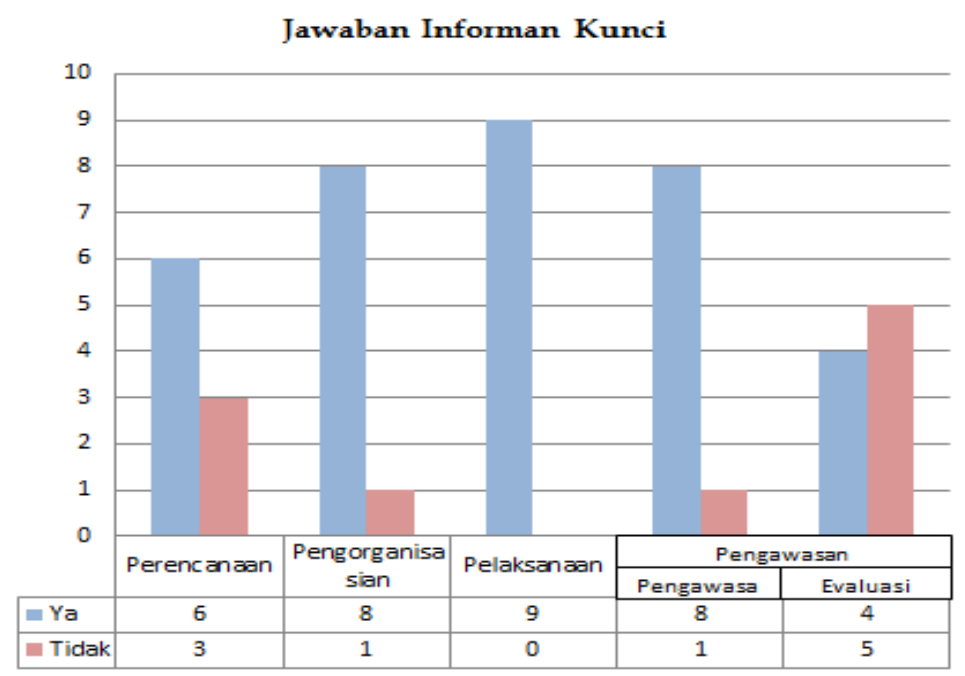

Berdasarkan tabel 3 tersebut dapat dijelaskan sebagai berikut:

1. Perencanaan

Indikator pertama perencanaan pada item pernyataan nomor 1 mendapatkan hasil bahwa sejumlah enam informan kunci menjawab "Ya" yang artinya dalam mengelola usaha perlu melakukan perencanaan bisnis untuk satu tahun kedepan dan tiga informan kunci menjawab "Tidak" yang artinya dalam mengelola usaha logam tidak perlu melakukan perencanaan bisnis untuk satu tahun kedepan.

2. Pengorganisasian

Indikator kedua pengorganisasian pada item pernyataan nomor 2 mendapatkan hasil bahwa delapan informan kunci menjawab "Ya" yang artinya perlunya memberikan tugas kepada karyawan sesuai dengan keahliannya agar mampu mempercepat selesainnya pekerjaan dan sebanyak satu informan kunci menjawab "Tidak". 


\section{Pelaksanaan}

Indikator ketiga pelaksanaan item pernyataan 3 pada penelitian mendapatkan hasil bahwa keseluruhan dari informan kunci menjawab "Ya" yang artinya aktivitas untuk mengarahkan semua karyawan yang dimiliki mampu memberikan efektifitas dan efisiensi bagi suatu usaha.

4. Pengawasan "Pengawasan"

Indikator keempat yaitu tahap pengawasan dengan mengukur proses pengawasan yang dilakukan pada item pernyataan nomor 4 tentang proses pengawasan mendapatkan hasil bahwa sebanyak delapan informan kunci menjawab "Ya" yang artinya selalu melakukan pengawasan dari awal proses produksi hingga produk siap untuk dikirim dan satu informan kunci lainnya menjawab "Tidak".

5. Pengawasan "Evaluasi atau Koreksi"

Indikator keempat pengawasan yang mencerminkan sikap melakukan proses evaluasi atau koreksi pada item pernyataan nomor 5 mendapatkan hasil sebanyak empat informan kunci menjawab "Ya" yang artinya melakukan evaluasi atau koreksi setiap bulannya dalam aktivitas kerja dan sebanyak lima informan kunci lainnya menjawab "Tidak” melakukan evaluasi atau koreksi setiap bulannya.

Penelitian yang dilakukan memberikan hasil bahwa kemampuan manajerial berperan terhadap kinerja perusahaan pada usaha logam skala mikro di Ngingas Sidoarjo. Indikator pertama perencanaan pada item pernyataan pertama memberikan hasil bahwa dalam mengelola usaha perlu melakukan perencanaan bisnis untuk satu tahun kedepan. Bentuk-bentuk perencanaan usaha menurut informan kunci adalah dengan diterapkannya perencanaan permodalan dan perputaran uang, produk yang diproduksi, pengembangan usaha, menjaga loyalitas pelanggan, dan pemenuhan target penjualan. Indikator kedua pengorganisasian pada item pernyataan kedua dalam memberikan tugas kepada karyawan sesuai keahliannya mampu mempercepat selesainnya pekerjaan. Indikator ketiga pelaksanaan pada item pernyataan ketiga memberikan hasil bahwa dengan mengarahkan semua karyawan yang dimiliki mampu memberikan efektifitas dan efisiensi usaha. Indikator keempat pengawasan pada item pernyataan keempat pengawasan memberikan hasil bahwa proses pengawasan selalu mereka lakukan dari awal proses produksi hingga produk siap untuk dikirim. Pengawasan langsung yang dilakukan untuk memantau jalannya proses produksi mulai 
dari awal produksi dalam memilih bahan baku yang digunakan, proses finishing dan pendistribusian produk ke konsumen. Indikator keempat pengawasan pada item pernyataan kelima evaluasi atau koreksi memberikan hasil bahwa informan kunci sebenarnya melakukan evaluasi atau koreksi namun tidak setiap bulan sekali hal tersebut dilakukan. Aktivitas evaluasi atau koreksi tidak dilakukan setiap bulan sekali karena sistem produksi logam yang membutuhkan waktu lama dan mereka lebih mementingkan evaluasi atau koreksi jika pendapatan yang diterima berkurang atau sedang terjadi masalah dalam usaha mereka. Hasil penelitian sejalan dengan penelitian yang dilakukan oleh Hsi-Yin Lo (2012) bahwa kemampuan manajerial dan budaya organisasi berdampak pada kinerja perusahaan hotel di China dan Sani et al. (2015) bahwa kemampuan manajemen yang baik berpengaruh signifikan terhadap kinerja UKM di Nigeria Bagian Utara.

\section{KESIMPULAN DAN SARAN}

\section{Kesimpulan}

1. Lingkungan industri dalam hal ini pada indikator hambatan masuknya pesaing baru, kekuatan pemasok, kekuatan pembeli, dan ketersediaan barang subsitusi berperan terhadap kinerja perusahaan pada usaha logam skala mikro di Ngingas Sidoarjo. Lingkungan industri pada indikator pesaing kompetitif tidak berperan terhadap kinerja perusahaan pada usaha logam skala mikro di Ngingas Sidoarjo.

2. Perilaku kewirausahaan berperan terhadap kinerja perusahaan pada usaha logam skala mikro di Ngingas Sidoarjo.

3. Kemampuan manajerial berperan terhadap kinerja perusahaan pada usaha logam skala mikro di Ngingas Sidoarjo.

\section{Saran}

1. Proses produksi logam pada usaha logam skala mikro di Ngingas Sidoarjo sebagian besar mengandalkan pesanan yang didapatkan dari konsumen ataupun pelanggan tetapnya, oleh karena itu diperlukan suatu jaringan kemitraan dengan pemasok.

2. Para pelaku usaha logam skala miko di Ngingas Sidoarjo Sikap harus berperilaku kewirausahaan dan memiliki kemampuan manajerial dalam mengelola usahanya dengan harapan kinerja usaha selalu meningkat dan loyalitas pelanggan tetap terjaga. 
3. Diperlukan sebuah sistem pencatatan laporan keuangan yang baik sehingga cash flow laba rugi setiap tahunnya terukur.

\section{DAFTAR PUSTAKA}

Dharma, Surya. (2009). Manajemen Kinerja Falsafah, Teori, dan Penerapan. Yogyakarta: Pustaka Pelajar.

Hajar, Ibnu dkk. (2012). "Pengaruh Kemampuan Manajerial dan Lingkungan Industri terhadap Kemampuan Organisasi, Strategi Bersaing, dan Kinerja Perusahaan (Studi pada Industri Kecil Meubel Kayu di Sulawesi Tenggara)". Jurnal Aplikasi Manajemen. Vol. 10 (2): hal. 291-302.

Hamdani, M. (2010). Entrepreneurship: Kiat Melihat \& Memberdayakan Potensi Bisnis. Yogyakarta: Starbooks.

Hsi-Yin Lo. (2012). "Managerial Capability, Organizational Culture and Organizational Performance: The Resource-Based Perspective in Chinese Lodging Industry". The Journal of International Management Studies. Vol. 7 (1): hal. 151-157.

Irawan dan Bayu. (2007). Kewirausahaan UMKM: Pemikiran dan Pengalaman/FE Ubaya dan Forda UMKM Jawa Timur. Yogyakarta: Graha Ilmu.

Kraus, Sascha et al. (2012). "Entrepreneurial Orientation and The Business Performance of SMEs: a Quantitative Study From The Netherlands". International Journal of Business and Management. Vol. 6 (1): hal. 161-182.

Kristanto, Heru. (2009). Kewirausahaan: Pendekatan Manajemen dan Praktik. Yogyakarta: Graha Ilmu.

Nur, Nofal. (2014). "Entrepreneurship Orientation, Market Orientation, Business Strategy, Management Capability on Business Performance: Study at Small and Medium Enterprise Printing ini Kendari”. International Journal of Business and Management Invention. Vol. 3 (12): hal. 08-17.

P, Stephen Robbins dan Mary Coulter. (2010). Manajemen Edisi Kesepuluh. Jakarta: Erlangga.

Puji, Rahayu Suci. (2009). "Orientasi Kewirausahaan, Dinamika Lingkungan, dan Kemampuan Manajemen serta Dampaknya Terhadap Kinerja (Studi pada Industri kecil Menengah Bordir di Jawa Timur)". Jurnal Aplikasi Manajemen. Vol. 7 (2): hal. 335-344.

Rahayu, Mintarti. (2013). Manajemen Strategik Kewirausahaan. Malang: Universitas Brawijaya Press.

Sani, Bello Sambo et al. (2015). "Effect of Entrepreneurial Skills Management and Funding on Small and Medium Enterprises' Performances at The Local 
Gevernment Level ini Northern Nigeria”. International Journal of Academic Research in Business and Social Science. Vol. 5 (6): hal. 338-348.

Setyamusa, Dodi. (2009). Kewirausahaan. Yogyakarta: Graha Ilmu.

Shafinaz, Azlin Arshad et al. (2014)). "The Impact of Entrepreneurial Orientation on Business Performance: A Study of Technology-based SMEs in Malaysia". Social and Behavioral Sciences. Vol. 130: hal. 46-53.

Solihin, Ismail. (2009). Pengantar Manajemen. Jakarta: Erlangga.

Suryana. (2003). Kewirausahaan. Jakarta: Salemba Empat.

Sutarno. (2010). Serba - Serbi Manajemen Bisnis. Yogyakarta: Graha Ilmu.

Udaya, Jusuf dkk. (2013). Manajemen Stratejik. Yogyakarta: Graha Ilmu.

Zakiyudin, Ais. (2013). Teori dan Praktik Manajemen Sebuah Konsep yang Aplikatif Disertai Profil Kewirausahaan Sukses. Jakarta: Mitra Wacana Media. 